\title{
Outcome Prediction in Severe Burn Injury: Clinical Versus Laboratory Markers.
}

Nele BRUSSELAERS ${ }^{1,2}$, Stan MONSTREY ${ }^{2,3}$, Dirk VOGELAERS ${ }^{1,2}$, Stijn BLOT ${ }^{1,2}$

${ }^{1}$ Dept. General Internal Medicine, Ghent University Hospital, Ghent, Belgium

${ }^{2}$ Faculty of Medicine and Health Sciences, Ghent University, Ghent, Belgium

${ }^{3}$ Dept. Plastic Surgery and Burn Unit, Ghent University Hospital, Ghent, Belgium

Corresponding author:

Nele BRUSSELAERS

Dept. General Internal Medicine

Ghent University Hospital

9000 Ghent - Belgium

T: 003293320339

Nele.Brusselaers@UGent.be

Key words : burn injury, outcome prediction, mortality 
Dear Editor,

We've read with interest the article of Altrichter et al, in which circulating free-DNA neutrophil extracellular traps (cf-DNA/NETs) were used in the prediction of mortality in a population of 32 patients with severe burn injury [1]. These extracellulary DNA structures (produced by neutrophils as defense mechanism trapping and killing pathogens) have previously shown to predict sepsis and mortality in multi-trauma patients [1]. In outcome prediction, mortality is the most objective endpoint, although sepsis and multi-organ failure are also important endpoints [2, 3]. Outcome prediction has several purposes. The 'severity' of a population with burn injury can be assessed, e.g. for research, bench marking and resource allocation. Outcome prediction can also be beneficial on patient-level, although this should be performed more cautiously.

We were intrigued to read that these cf-DNA/NETs structures could be more beneficial compared with scoring systems based on simple demographic or clinical parameters, especially early after admission. Previous research repeatedly showed the high predictive value of increasing age and total burned surface area (TBSA) and the presence of an inhalation injury [4]. These factors are used in the Belgian Outcome in Burn Injury (BOBI) prediction model which repeatedly proved to be easy-to-use and reliable [5-7]. In addition, it is definitely less costly since no further (laboratory) analyses are needed as in the study of Altrichter [1]. In the study by Altrichter et al., these cfDNA/NET markers were compared with the rather outdated ABSI model (1982), after which more than a dozen new severity scoring systems have been developed $[5,8-10]$. Since outcome data in burn injury have improved significantly over the last few decades [4, 11], more recent prediction models could be a better match. Based on the data presented in the article by Altrichter et al, we calculated the predictive value of the BOBI model in this cohort. The ROC-curve analysis, which combines sensitivity and specificity of a test, showed a better predictive value, with a larger area under the curve 
and smaller $95 \%$ confidence intervals, than obtained with the cf-DNA/NETs marker: $0.93(0.84-1.00)$ vs. $0.85(0.68-1.00)$; but as seen in the article of Altrichter, even the 30y old ABSI model appeared to be notably better than the DNA marker with especially a higher specificity and positive predictive value (respectively $92 \%$ and $75 \%$ for the ABSI model vs. $76 \%$ and $46 \%$ for the cf-DNA/NETs marker). Therefore, we agree with the authors, that a single parameter such as the cf-DNA/NETs marker should never be used as only predictor of mortality [1].

For that reason, we question the clinical benefit of a laboratory marker on 'outcome' prediction. Nevertheless, laboratory markers are probably of a higher use in prediction of sepsis and organ failure, since earlier and more accurate treatment of these complications may result in a better outcome [2, 12-15]. A high specificity (few false positive) would then be advisable to avoid unnecessary, potentially harmful treatment. However, especially the positive predictive value of cf-DNA/NETs appears to be poor in this cohort (only $46 \%$ ).

\section{References}

[1] Altrichter J, Zedler S, Kraft R, Faist E, Mitzner SR, Sauer M, et al. Neutrophil-derived circulating free DNA (cf-DNA/NETs), a potential prognostic marker for mortality in patients with severe burn injury. Eur J Emerg Surg 2010; 36: 551-557.

[2] Lorente JA, Vallejo A, Galeiras R, Tomicic V, Zamora J, Cerda E, et al. Organ dysfunction as estimated by the sequential organ failure assessment score is related to outcome in critically ill burn patients. Shock 2009; 31: 125-31.

[3] Saffle JR, Sullivan JJ, Tuohig GM, Larson CM. Multiple organ failure in patients with thermal injury. Crit Care Med 1993; 21: 1673-83.

[4] Brusselaers N, Hoste EA, Monstrey S, Colpaert KE, De Waele JJ, Vandewoude KH, et al. Outcome and changes over time in survival following severe burns from 1985 to 2004. Intensive Care Med 2005; 31: 1648-53.

[5] The Belgian Outcome in Burn Injury Study Group. Development and validation of a model for prediction of mortality in patients with acute burn injury. Br J Surg 2009; 96: 111-7.

[6] Brusselaers N, Juhasz I, Erdei I, Monstrey S, Blot S. Predictive value of the Belgian Outcome in Burn Injury (BOBI) prediction model. Burns 2010; 36: 1318-19.

[7] Brusselaers N, Juhasz I, Erdei I, Monstrey S, Blot S. Evaluation of mortality following severe burns injury in Hungary: external validation of a prediction model developed on Belgian burn data. Burns 2009; 35: 1009-14. 
[8] Gomez M, Wong DT, Stewart TE, Redelmeier DA, Fish JS. The FLAMES score accurately predicts mortality risk in burn patients. J Trauma 2008; 65: 636-45.

[9] Griffe O, Gartner R, Captier G, Brabet M, Baro B, Selloumi D, et al. [Evaluation of prognostic factors in the burned patient]. Ann Chir Plast Esthet 2001; 46: 167-72.

[10] McGwin G, Jr., George RL, Cross JM, Rue LW. Improving the ability to predict mortality among burn patients. Burns 2008: 320-327.

[11] Brusselaers N, Monstrey S, Vogelaers D, Hoste E, Blot S. Severe burn injury in Europe: a systematic review of the incidence, aetiology, morbidity and mortality. Crit Care 2010; 14: R188.

[12] Lavrentieva A, Kontakiotis T, Lazaridis L, Tsotsolis N, Koumis J, Kyriazis G, et al. Inflammatory markers in patients with severe burn injury. What is the best indicator of sepsis? Burns 2007; 33: 189-94.

[13] Barati M, Alinejad F, Bahar MA, Tabrisi MS, Shamshiri AR, Bodouhi NO, et al. Comparison of WBC, ESR, CRP and PCT serum levels in septic and non-septic burn cases. Burns 2008; 34: 770-4.

[14] Moreno RP, Metnitz B, Adler L, Hoechtl A, Bauer P, Metnitz PG. Sepsis mortality prediction based on predisposition, infection and response. Intensive Care Med 2008; 34: 496-504.

[15] Brusselaers N, Monstrey S, Colpaert K, Decruyenaere J, Blot SI, Hoste EA. Outcome of acute kidney injury in severe burns: a systematic review and meta-analysis. Intensive Care Med 2010; 36: 915-25. 